OPEN ACCESS

Edited by: Jane A Entwistle, Northumbria University, United Kingdom

Reviewed by:

Anna Lenart-Boroń, University of Agriculture in Krakow. Poland Kiri Rodgers, University of the West of Scotland, United Kingdom

*Correspondence:

Ewa Brągoszewska ewa.bragoszewska@polsl.pl

Received: 14 May 2021 Accepted: 18 August 2021 Published: 17 September 2021

Citation: Brągoszewska E and Biedroń I (2021) Efficiency of Air Purifiers at Removing Air Pollutants in Educational Facilities: A Preliminary Study.

Front. Environ. Sci. 9:709718. doi: 10.3389/fenvs.2021.709718

\section{Efficiency of Air Purifiers at Removing Air Pollutants in Educational Facilities: A Preliminary Study}

\author{
Ewa Brągoszewska ${ }^{1 *}$ and Izabela Biedron ${ }^{2}$ \\ ${ }^{1}$ Department of Technologies and Installations for Waste Management, Silesian University of Technology, Gliwice, Poland, \\ ${ }^{2}$ Faculty of Science, Universität Bern, Bern, Switzerland
}

Infectious diseases caused by airborne bacteria and viruses are a major problem for both social and economic reasons. The significance of this phenomenon is particularly noticeable during the time of the coronavirus pandemic. One of the consequences is the increased interest in the air purifier (AP) market, which resulted in a significant increase in sales of these devices. In this study, we tested the efficiency of APs in removing bacterial air contamination in the educational context in the Upper Silesia region of Poland during the "cold season" of 2018/2019. During the 6 months of measuring microbiological air quality, an $18 \%$ decrease in the concentration of microbiological pollutants as a result of the action of the APs was recorded. Additionally, the results of the particle size distribution of the bacterial aerosols showed a reduction in the share of the respirable fraction (particles with an aerodynamic diameter below $3.3 \mu \mathrm{m}$ ) by an average of $20 \%$. The dominance of gram-positive cocci in the indoor environment indicates that humans are the main source of most of the bacteria present in the building. We conclude that the use of APs may significantly decrease the level of concentration of microbiological air pollutants and reduce the negative health effects of indoor bioaerosols; however, further work that documents this phenomenon is needed.

Keywords: indoor air quality (IAQ), kindergarten, bioaerosol, air purifiers (APs), bacterial aerosol

\section{INTRODUCTION}

People spend about $80-95 \%$ of their lives in indoor spaces and breathe in around $10 \mathrm{~m}^{3}$ of air every day (Lee and Chang, 1986; Dacarro et al., 2003; Tringe et al., 2008). Moreover, "people inhale 6-10 L of air per minute, which amounts to 15,000 L/day" (Wood et al., 2002). According to measurements conducted in the last 20 years by the US Environmental Protection Agency, the air in indoor spaces is sometimes $\sim 100$ times more polluted than atmospheric air and indoor air pollution is one of the top five health hazards (Kotzias, 2005; Gawrońska and Bakera, 2015).

The increased susceptibility of children to air pollution is associated with their much more varied activity during the day, the fact that they inhale a greater volume of air in relation to their body size and the incomplete maturity of their immune systems (Branco et al., 2014; WHO, 2018). Air quality in indoor environments, such as nurseries, where children stay for up to $40 \mathrm{~h}$ per week, is particularly important because children are a key vulnerable group and may be exposed to lung damage and infections associated with poor indoor air quality (IAQ) (Bragoszewska et al., 2018a; Oliveira et al., 2019; Chegini et al., 2020). 
The basic indicator of indoor air pollution is the concentration of bioaerosols (Jiayu et al., 2019). When it comes to negative health effects, bioaerosols play an important role as risk factors. Biological aerosols are pollutant particles that include microorganisms such as bacteria, fungal spores, viruses, or pollen grains and are always present in the air (Adhikari et al., 2006; Brągoszewska and Pastuszka, 2018; Tolabi et al., 2019).

The main source of bacterial aerosols in kindergartens has been traced to the presence and activities of people (Bragoszewska et al., 2016a; Canha et al., 2016; Bragoszewska et al., 2018b). It should also be noted that microorganisms can colonize an educational building's heating and ventilation system (Oh et al., 2014; Brągoszewska et al., 2018a; Bragoszewska and Biedroń, 2018).

Exposure to bacterial aerosols in kindergartens is associated with a varied range of health effects, including three major groups: infections, toxic reactions, and allergic reactions (Zelles, 1999; Pastuszka, 2001; Douwes et al., 2003; Brągoszewska and Pastuszka, 2018; Gołofit-Szymczak and Górny, 2018; Chegini et al., 2020). The aerodynamic diameter of biological aerosols is strongly related to their deposition site in the human respiratory tract; hence, their health effect is heavily dependent on their physical qualities, particularly their size distribution (Nevalainen et al., 1993; Thorn and Kerekes, 2001; Liebers et al., 2008; Nasir and Colbeck, 2010; Degobbi et al., 2011).

Sales of air purifiers (APs) have risen considerably, from 0.8 million units in 2015 to almost two million units in 2018, and this trend is projected to continue. AP sales have increased, which has resulted in a rise in the amount of energy used by APs (Kim et al., 2019). The use of APs can be one way to achieve IAQ improvement. APs with high-efficiency particulate air (HEPA) filters are highly effective in removing biological aerosols in indoor environments. HEPA filters in APs are widely used in Poland, which is a consequence of increasing public awareness of the impact of IAQ on health. In HEPA APs, the air is forced through the HEPA filter, and particles are physically captured (through diffusion, interception, inertial impaction, and sieving) (Yang, 2012). It is estimated that HEPA filters process particles of more than $0.3 \mu \mathrm{m}$ with $99.97 \%$ efficiency fibers and could filter particles greater than $0.3 \mu \mathrm{m}$ through impaction and interception (Gorji et al., 2017).

There is also limited evidence that these decreases result in improved cardiorespiratory health (Fisk, 2013; Morishita et al., 2015). APs usage has been associated with decreased blood pressure, reduced oxidative stress, reduced systemic inflammation, and enhanced lung function in a number of studies (Kelly and Fussell, 2019).

The COVID-19 pandemic has forced a significant focus on indoor disinfection and air purification options. The most frequent applications are the local control of the source of pollution, disinfection of rooms and surfaces, and ventilation. The use of APs can be considered an additional complementary and preventive action in the spread of biological contamination. Adequate IAQ can be achieved mainly by reducing and constantly controlling the concentrations of harmful microorganisms in the air.
TABLE 1 | The main characteristics of the studied nursery school in Gliwice, Poland.

\begin{tabular}{lc} 
Parameters & \\
\hline Volume, $\mathrm{m}^{3}$ & 300 \\
Period of measurements & $10: 00-12: 00$ (CET) \\
Number of children in the group & 22 \\
Age of children & $5-6$ years \\
Number of staff present in the sampled site & $1-2$ \\
Indoor temperature, ${ }^{\circ} \mathrm{C}$ & \\
Sep & 21.6 \\
Oct & 22.5 \\
Nov & 23.1 \\
Dec & 23.2 \\
Jan & 23.3 \\
Feb & 23.1 \\
Indoor relative humidity $(\mathrm{RH}), \%$ & \\
Sep & 34.2 \\
Oct & 36.1 \\
Nov & 35.3 \\
Dec & 34.1 \\
Jan & 33.8 \\
Feb & 34.3
\end{tabular}

The limited data on IAQ in Polish educational institutions and the lack of generalized standards for bioaerosol levels are the reason why the presented studies can increase awareness and focus more attention on IAQ issues.

According to the Air Quality in Europe 2020 report published by the European Environment Agency (EEA), Poland has the European Union's most polluted air. The report found that the concentration of both PM10 and PM2.5-two types of harmful airborne participate matter-was higher in Poland than in any other European Union (EU) country. The collected data can be used to assess the exposure of children and kindergarten staff in southern Silesia, which is one of the most polluted areas in the EU. The specific aims include (i) the evaluation of the impact of APs on the microbial IAQ, (ii) investigation of the concentration levels of culturable bacteria, (iii) determination of the size distributions with particular attention to the respirable fraction of bacterial aerosols, and (iv) examination of the bacterial community structure.

\section{MATERIALS AND METHODS}

\section{Sampling Sites}

The study was carried out in a kindergarten located in Gliwice $(50.324,666 \mathrm{~N}, 18.711,405 \mathrm{E})$. Gliwice is a typical example of a city located in the industrial region of Upper Silesia, Poland, with 178.186 thousand occupants. The surrounding area of the measurement point is characterized by compact building development. Buildings, roads, asphalt, etc., cover most of the surfaces in this part of the city. More detailed information about the main characteristics of the studied kindergarten in Gliwice is provided in Table 1.

Air sampling was conducted during the "cold season," from September 2018 to February 2019. The sampling was performed two times each week, with one sample taken outside the building 
TABLE 2 | Summary of sampling details for nursery school in Gliwice (Poland).

\begin{tabular}{|c|c|c|c|c|}
\hline Date of sampling & Sampling frequency & $\begin{array}{c}\text { Total samples when } \\
\text { air purifier was } \\
\text { off }\end{array}$ & $\begin{array}{c}\text { Total samples when } \\
\text { air purifier was } \\
\text { active }\end{array}$ & Total samples outdoor \\
\hline Sep & 8 times per month & 96 & 96 & 96 \\
\hline Oct & 8 times per month & 96 & 96 & 96 \\
\hline Nov & 8 times per month & 96 & 96 & 96 \\
\hline Dec & 8 times per month & 96 & 96 & 96 \\
\hline Jan & 8 times per month & 96 & 96 & 96 \\
\hline Feb & 8 times per month & 96 & 96 & 96 \\
\hline
\end{tabular}

and two indoors, one when the APs were turned off and the other after $60 \mathrm{~min}$ from turning the APs on (Table 2). Two sets of measurements were performed with the APs turned on. Samples were collected between 10:00 and 12:00 local time, in order to check the efficiency of the tested device. The kindergarten had natural ventilation and was insulated and windows were kept closed during the sampling.

\section{Field Sampling}

Bioaerosols were collected using an Andersen cascade impactor (Thermo Fisher Scientific, Waltham, MA, United States) with cut-off diameters of $7.0,4.7,3.3,2.1,1.1$, and $0.65 \mathrm{~m}$ and quantified as bacterial colony-forming units per cubic meter of air $\left(\mathrm{CFU} / \mathrm{m}^{3}\right)$.

According to Nevalainen et al. (1993), the sample time was $10 \mathrm{~min}$, and the impactor pump maintained a constant flow rate of $28.3 \mathrm{dm}^{3} / \mathrm{min}$. To speciate bacterial aerosols, researchers used tryptic soy agar (TSA \%, Biocorp, Poland) growth media with cycloheximide added. At $36 \pm 1^{\circ} \mathrm{C}$, the samples were incubated for $48 \mathrm{~h}$.

\section{Identification of Selected Bacteria}

Single colonies were passaged on Biolog Universal Growth Agar $\left(24 \mathrm{~h}\right.$ incubation at $37^{\circ} \mathrm{C}$ ) after a $24 \mathrm{~h}$ incubation on TSA plates. Gram staining and cell morphology were used to further characterize the isolates.

Selected strains were then identified using the Biolog OmniLog system (Biolog, Haward, CA, United States) and GEN III MicroPlate $^{\mathrm{TM}}$ as in our previous studies (Bragoszewska and Biedroń, 2018; Bragoszewska et al., 2018a).

\section{Characteristics of the Used AP}

The used AP had a PET prefilter that kept bigger pollutants out, a HEPA-11 filter with a $2.2 \mathrm{~m}^{2}$ surface area, and an adsorption filter with active carbon (with an absorbing area of $57,000 \mathrm{~m}^{2}$ ). The Clean Air Delivery Rate (CADR) value obtained from the AP was $310 \mathrm{~m}^{3} / \mathrm{h}$. CADR is the international standard for measuring AP effectiveness. The higher the CADR is, the more particles the air cleaner can filter and the larger the area it can serve (ASHRAE, 2019).

\section{Statistical Analyses}

All statistical analyses were performed with R Studio 1.3.1073, and plots were created with the ggplot2 package.
Due to a nonparametric distribution of the collected data (analyzed with the Shapiro-Wilk test), results were analyzed using the Mann-Whitney $U$ test to assess differences at the sampling sites. Statistically significant differences were determined when a probability $p$-value was lower than 0.05 .

\section{RESULTS AND DISCUSSION}

\section{Total Bacterial Aerosols When AP Was Off (APO), When AP Was Active (APA), and From Outdoors (OUT)}

The mean $( \pm S D)$ concentration of bacterial aerosols and the efficiency of the AP during the 6 months of measurements are summarized in Table 3.

The Mann-Whitney $U$ test confirmed significant differences in the concentration levels of bacterial aerosols between when APO and when APA with $p$-values $<0.05$. The average concentration of bacterial aerosols when APO and when APA was $1208 \mathrm{CFU} / \mathrm{m}^{3}$ and $986 \mathrm{CFU} / \mathrm{m}^{3}$, respectively. The highest value of bacterial aerosols was detected in November (2257 CFU/ $\mathrm{m}^{3}$ ) when APO. While APA, the maximum value of bacterial aerosols was also found in November, but it was 1.3 times lower $\left(1675 \mathrm{CFU} / \mathrm{m}^{3}\right)$ than the highest observed APO value.

Microbiological IAQ during 6 months of our measurements, when APA, was on average almost $18 \%$ better than in cases where there were no procedures to decrease the concentration of microbiological air pollutants. The highest average value efficiency of the AP was found in November (26\%) and the lowest during February (11\%) (Figure 1). In our opinion, the analyzed AP device employed has one of the best particle capture capacities within the aerodynamic diameter range from 1.1 to $2.1 \mu \mathrm{m}$. In November, the specific conditions, predominance of particles in size range from 1.1 to $2.1 \mu \mathrm{m}$ (Figure 2), and the specific characteristics of the device (high efficiency in this size range) resulted in the observed peak in the mean AP efficiency (26\%).

In our previous study conducted in Polish dwellings, the concentration of bacterial aerosols was reduced by almost $50 \%$ when APs were enabled (Bragoszewska et al., 2019). Similar studies conducted in Poland indicate that the effectiveness of APs for the reduction of particulate matter (PM) in kindergartens was $41 \%$ (Gayer et al., 2018). 
TABLE 3 | Average concentration $( \pm \mathrm{SD})$ concentration of culturable bacteria colony-forming units per cubic meter of air $\left(\mathrm{CFU} / \mathrm{m}^{3}\right)$ inside nursery school during two cycles: when air purifier was off (APO)/when air purifier was active (APA) and outdoor (OUT).

\begin{tabular}{|c|c|c|c|c|c|c|c|c|}
\hline \multirow[t]{2}{*}{ Months } & \multicolumn{2}{|l|}{ OUT } & \multicolumn{3}{|c|}{ APO } & \multicolumn{3}{|c|}{ APA } \\
\hline & Average concentration & SD & Average concentration & SD & I/O ratio & Average concentration & SD & I/O ratio \\
\hline Sep & 491 & 138 & 1,066 & 214 & 2.17 & 899 & 101 & 1.83 \\
\hline Oct & 426 & 70 & 1756 & 331 & 4.12 & 1,486 & 238 & 3.49 \\
\hline Nov & 551 & 78 & 2,257 & 743 & 4.09 & 1,675 & 448 & 3.04 \\
\hline Dec & 325 & 57 & 803 & 151 & 2.47 & 659 & 130 & 2.03 \\
\hline Jan & 309 & 62 & 623 & 77 & 2.02 & 531 & 100 & 1.72 \\
\hline Feb & 303 & 66 & 744 & 127 & 2.46 & 663 & 122 & 2.19 \\
\hline
\end{tabular}
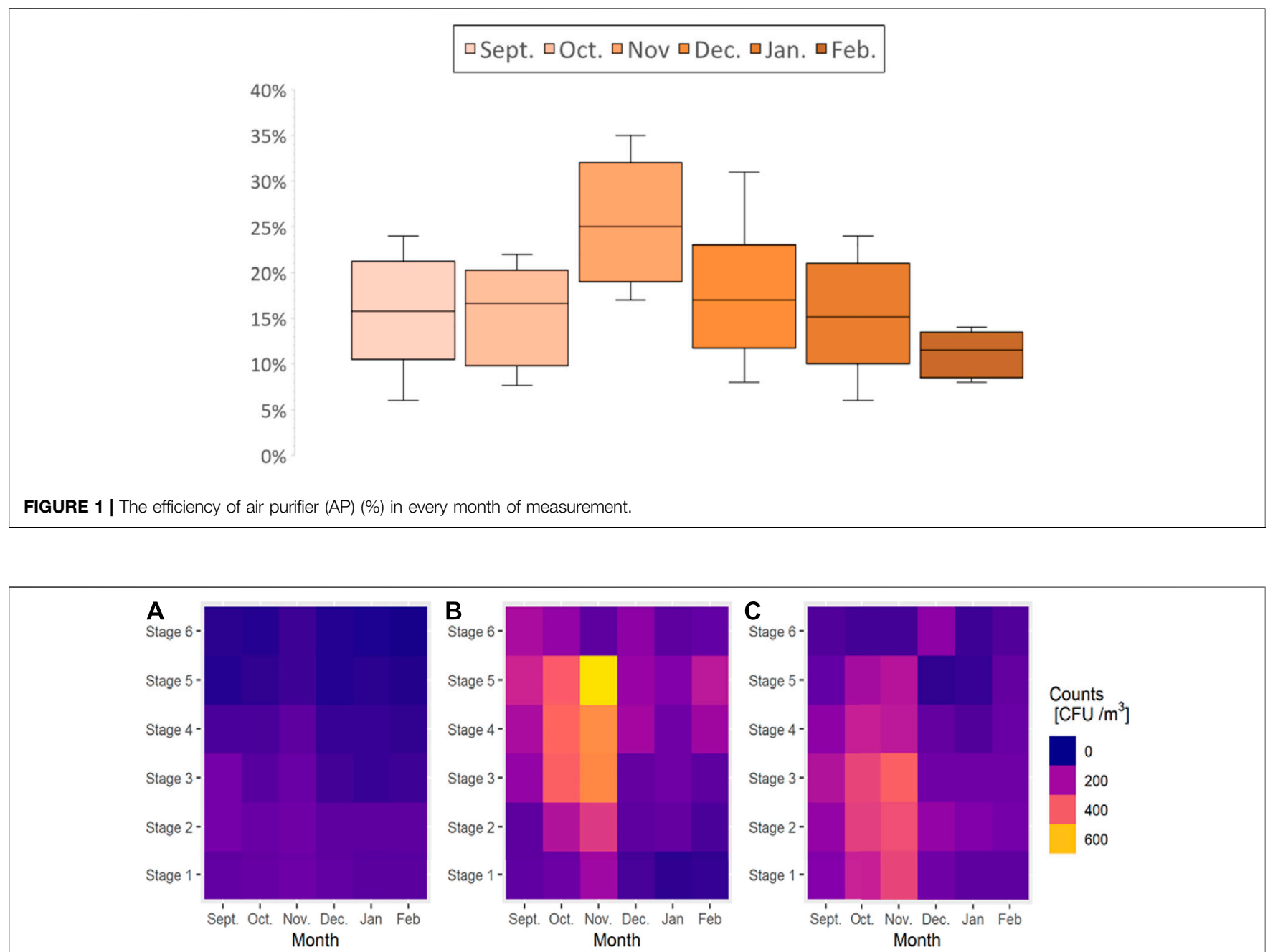

FIGURE 2 | The size distribution of bacterial aerosol collected by using an Andersen impactor with different aerodynamic diameter stages: stage 1: >7.0 4 m; stage

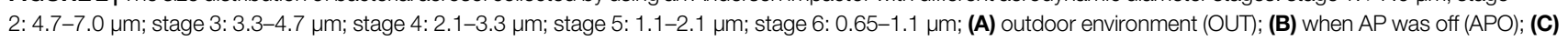
when AP was active (APA).

Previously conducted studies have shown that HEPA filters can reduce particle number concentrations by more than $50 \%$ (Batterman et al., 2012; Wheeler et al., 2014; Kelly and Fussell, 2015). The removal efficiency of bioaerosols in Seoul, Korea, was as high as $68 \%$ for airborne bacteria (Oh et al., 2014). In our previous study conducted in Polish dwellings, the average air purification efficiency in the elimination of the total concentration of bacterial aerosols was near $50 \%$ (Bragoszewska et al., 2019).

The average level of bacterial aerosol concentration in the indoor air exceeded almost threefold the average level recorded in the outdoor air $\left(401 \mathrm{CFU} / \mathrm{m}^{3}\right)$. The ratio values of indoor to 
FIGURE 3 | The share of the respirable fraction of bacterial aerosols when APO/when APA.

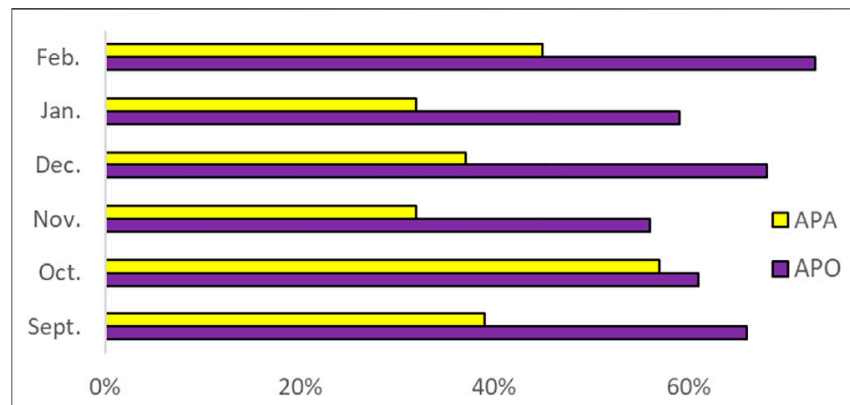

Share of the respirable fraction (particles less than $3.3 \mu \mathrm{m}$ ) [\%]

TABLE 4 | Bacterial species identified inside nursery school during two cycles: when APO/when APA and outdoor (OUT).

\begin{tabular}{lccc}
$\begin{array}{l}\text { Species } \\
\text { of isolated bacteria }\end{array}$ & OUT & APO & APA \\
\hline Micrococcus luteus & & & + \\
Macrococcus equipercicus & + & + & + \\
Staphylococcus epidermis & - & + & + \\
Staphylococcus hominis & - & - & - \\
Streptococcus sobrinus & - & + & + \\
Nocardia alba & - & - & + \\
Bacillus flexus & + & + & + \\
Bacillus licheniformis & + & + & + \\
Lactobacillus crispatus & + & + & + \\
Paenibacillus barengoltzii & + & + & + \\
Pseudomonas stutzeri & + & - & + \\
Acinetobacter Iwoffii & + & - & + \\
Pantoea eucrina & - & + & \\
Insolitispirillum peregrinum & + & & + \\
& - & &
\end{tabular}

outdoor bacteria numbers (I/O bacteria) are generally used as an identifier for emission sources of bioaerosols (Nasir and Colbeck, 2010; Gayer et al., 2018). If this ratio is $>1.0$, there is a difference between outdoor and indoor biological aerosol sources and the source exists in the indoor space (Brągoszewska et al., 2018b).

The calculated average $\mathrm{I} / \mathrm{O}$ ratios of bacterial aerosol levels according to 6 months of measurements are shown in Table 2. The average I/O bacteria value of 2.89 was obtained when APO, while the average I/O bacteria ratio when APA occurred at 2.50 . Because the $\mathrm{I} / \mathrm{O}$ ratio was greater than 1.0 , it is safe to assume that the primary sources of bacterial aerosol in this study are internal, such as building occupants (in this case, kindergarten personnel and children) and building components that support microbiological growth.

As mentioned in Table 2, during the 6 months of our study, the ratio of $\mathrm{I} / \mathrm{O}$ bacteria ranged from 1.72 to 4.12 , which implies that indoor air is the major source of bacterial bioaerosols. This result agrees with our previous study conducted in a nursery school in Gliwice (Brągoszewska et al., 2016b) and with the findings of Canha et al. (2016), Tolabi et al. (2019), and Aydogdu et al. (2010).

\section{The Size Distribution of Bacterial Aerosols}

The mean distributions of aerodynamic diameters of bacterial aerosol are shown in Figure 2. When the AP was turned off, the size distribution of bacterial aerosols was characterized by a substantial percentage of particles in the $1.1-2.1 \mathrm{~m}$ aerodynamic diameter $\left(\mathrm{d}_{\mathrm{ae}}\right)$ range. The results of size distributions may indicate that the particles of bacteria are relatively fresh and mostly of human origin. Because respirable particles (particles less than $3.3 \mathrm{~m}$ ) lead to respiratory symptoms, such findings could indicate the presence of a hazardous potential exposure (Owen et al., 1992; Lacey and Dutkiewicz, 1994).

The results of the share of the respirable fraction of bacterial aerosols when APO and when APA are shown in Figure 3. The obtained results of the size distribution indicate that the use of active APs reduced the participation of the respirable fraction of bacteria by $20 \%$ on average. In December, the AP reduced the concentration of the respirable fraction by half, from $68 \%$ (APO) to $37 \%$ (APA).

\section{Identification of Isolated Bacterial Aerosols When APO, When APA, and From OUT}

Four groups of airborne bacteria were identified: Gram-positive cocci, nonsporing gram-positive rods, sporing gram-positive rods, and gram-negative rods (Table 4). Eight species of bacteria were isolated both when APO and when APA: Micrococcus luteus, Macrococcus equipercicus, Nocardia alba, Bacillus flexus, Lactobacillus crispatus, Paenibacillus barengoltzii, and Insolitispirillum peregrinum. Interestingly, three species of bacteria were isolated only when APA: Staphylococcus epidermidis, Streptococcus sobrinus, and Acinetobacter lwoffi. Staphylococcus epidermidis and Acinetobacter lwoffii are recognized as normal flora of the skin. Streptococcus sobrinus is associated with dental caries especially among children (Ghasempour et al., 2013). When comparing the outdoor air and the indoor air, it can be noticed that gram-positive cocci dominated in enclosed spaces. Children's activity is normally high; thus, gram-positive cocci can be transmitted to the indoor air from their bodies and respiratory tracts. The results of the qualitative analysis of bacterial aerosols obtained in the kindergarten in Gliwice cohere with other researches (Lacey and Dutkiewicz, 1994; Pastuszka et al., 2000; Liebers et al., 2008; Dumała and Dudzińska, 2013; Canha et al., 2015; Jiayu et al., 2019; Kelly and Fussell, 2019).

Gram-positive rods were the dominant group of outdoor air bioaerosols. One of the leading representatives of this group is the genus Bacillus, the spores of which have remarkable resistance to chemical and physical factors. They are bacteria commonly found in soil and water as well as being a component of the normal flora of the skin and mucous membranes of humans and various animals (Menteşe et al., 2009).

In the tested air of a selected kindergarten, exposure to bacterial aerosols does not pose a direct threat of acute health effects. Nevertheless, long-term inhalation of such large doses of airborne microorganisms could have negative health consequences, especially in vulnerable people. These people may be more susceptible to upper respiratory tract illnesses 
and allergy symptoms such as headaches, watery eyes, itchy skin, and coughing (Kim and Kim, 2007).

Although the level of microbiological contamination in the examined kindergarten should be considered safe, one should still strive to improve IAQ by taking appropriate measures. It can be expected that, in the autumn season, the presence of children with symptoms of infection in the kindergarten will cause a significant increase in the level of pathogenic bacteria in the building. Therefore, it is strongly recommended to increase the air exchange rate.

\section{CONCLUSION}

This work reports the effect of APs on bacterial aerosols in a kindergarten in the city of Gliwice (Poland) during 6 months of the "cold season" in 2018/2019. We also collected samples from the outdoor air to determine the indoor/outdoor ratio.

The average concentration of airborne bacteria in the kindergarten when APA was $986 \mathrm{CFU} / \mathrm{m}^{3}$, whereas the average concentration of indoor culturable bacteria when APO was $1208 \mathrm{CFU} / \mathrm{m}^{3}$. Microbiological IAQ, when the APs were enabled, was on average almost $\sim 18 \%$ better than in those without any procedures to decrease air pollutant concentration, with the maximum value of AP efficiency in November (26\%).

The results of the size distribution of airborne bacteria indicate the significant role of indoor emission sources in the analyzed kindergarten. The use of active APs reduced the participation of the respirable fraction (the particles $<3.3 \mu \mathrm{m}$ ) of bacteria by $20 \%$ on average. It was observed that the best AP efficiency in each month of our measurement was achieved for bacteria with an aerodynamic diameter range from 1.1 to $2.1 \mu \mathrm{m}$ (stage 5 of the Andersen impactor).

There is a still lack of international standards for microbial IAQ. In conclusion, indoor bioaerosol measurements should be carried out more frequently and on a bigger scale. Portable and inexpensive APs have the potential to reduce people's exposure to

\section{REFERENCES}

Adhikari, A., Reponen, T., Grinshpun, S. A., Martuzevicius, D., and Lemasters, G. (2006). Correlation of Ambient Inhalable Bioaerosols with Particulate Matter and Ozone: A Two-Year Study. Environ. Pollut. 140, 16-28. doi:10.1016/ j.envpol.2005.07.004

ASHRAE (2019). New Guidance for Residential Air Cleaners. Retreived from: https://www.epa.gov/sites/production/files/2019-09/documents/harriman stephens_brennan_-_new_guidance_for_residential_air_cleaners_-_ashrae_ journal_sept-2019._web_version.pdf

Aydogdu, H., Asan, A., and Tatman Otkun, M. (2010). Indoor and Outdoor Airborne Bacteria in Child Day-Care Centers in Edirne City (Turkey), Seasonal Distribution and Influence of Meteorological Factors. Environ. Monit. Assess. 164, 53-66. doi:10.1007/s10661-009-0874-0

Batterman, S., Du, L., Mentz, G., Mukherjee, B., Parker, E., Godwin, C., et al. (2012). Particulate Matter Concentrations in Residences: An Intervention Study Evaluating Stand-Alone Filters and Air Conditioners. Indoor Air. 22, 235-252. doi:10.1111/j.1600-0668.2011.00761.x

Branco, P. T. B. S., Alvim-Ferraz, M. C. M., Martins, F. G., and Sousa, S. I. V. (2014). Indoor Air Quality in Urban Nurseries at Porto City: Particulate biological air pollutants in indoor areas, but further research is needed, notably into the reemission process caused by APs air blowing. The understanding of this relationship will serve as a crucial foundation for the development of AP technology.

\section{DATA AVAILABILITY STATEMENT}

The original contributions presented in the study are included in the article/supplementary material,; further inquiries can be directed to the corresponding author.

\section{AUTHOR CONTRIBUTIONS}

Conceptualization, EB; data curation, EB; methodology, EB and IB; supervision, EB; visualization, IB and EB; writing-original draft, EB and IB; writing-review and editing, EB and IB.

\section{FUNDING}

This publication was supported in part by the Rector's Habilitation Grant, Silesian University of Technology, grant number 08/030/RGH19/0069, and by subsidies granted from the Department of Technology and Installations for Waste Management, Silesian University of Technology, grant number 08/030/BK_21/0089.

\section{ACKNOWLEDGMENTS}

The authors thank Rafał Szlosarek, a graduate of the Silesian University of Technology, for his help during the measurement sessions. The authors would like to thank the Department of Air Protection, Silesian University of Technology, for the possibility of using the laboratory.

Matter Assessment. Atmos. Environ. 84, 133-143. doi:10.1016/ j.atmosenv.2013.11.035

Brągoszewska, E., and Biedroń, I. (2018). Indoor Air Quality and Potential Health Risk Impacts of Exposure to Antibiotic Resistant Bacteria in an Office Rooms in Southern poland. Ijerph 15, 2604. doi:10.3390/ijerph15112604

Brągoszewska, E., Biedroń, I., Kozielska, B., and Pastuszka, J. S. (2018a). Microbiological Indoor Air Quality in an Office Building in Gliwice, Poland: Analysis of the Case Study. Air Qual. Atmos. Health. 11, 729-740. doi:10.1007/ s11869-018-0579-z

Brągoszewska, E., Bogacka, M., and Pikoń, K. (2019). Efficiency and Eco-Costs of Air Purifiers in Terms of Improving Microbiological Indoor Air Quality in Dwellings-A Case Study. Atmosphere 10, 742. doi:10.3390/ATMOS10120742

Brągoszewska, E., Mainka, A., and Pastuszka, J. (2016b). Bacterial and Fungal Aerosols in Rural Nursery Schools in Southern Poland. Atmosphere 7, 142. doi:10.3390/atmos7110142

Brągoszewska, E., Mainka, A., Pastuszka, J., Lizończyk, K., and Desta, Y. (2018b). Assessment of Bacterial Aerosol in a Preschool, Primary School and High School in Poland. Atmosphere 9, 87. doi:10.3390/atmos9030087

Brągoszewska, E., Mainka, A., and Pastuszka, J. S. (2016a). Bacterial Aerosols in an Urban nursery School in Gliwice, Poland: a Case Study. Aerobiologia 32, 469-480. doi:10.1007/s10453-015-9419-x 
Brągoszewska, E., and Pastuszka, J. S. (2018). Influence of Meteorological Factors on the Level and Characteristics of Culturable Bacteria in the Air in Gliwice, Upper Silesia (Poland). Aerobiologia 34, 241-255. doi:10.1007/s10453-018-9510-1

Canha, N., Almeida, S. M., Freitas, M. D. C., and Wolterbeek, H. T. (2015). Assessment of Bioaerosols in Urban and Rural Primary Schools Using Passive and Active Sampling Methodologies. Arch. Environ. Prot. 41, 11-22. doi:10.1515/aep-2015-0034

Canha, N., Mandin, C., Ramalho, O., Wyart, G., Ribéron, J., Dassonville, C., et al. (2016). Assessment of Ventilation and Indoor Air Pollutants in nursery and Elementary Schools in France. Indoor Air 26, 350-365. doi:10.1111/ina.12222

Chegini, F. M., Baghani, A. N., Hassanvand, M. S., Sorooshian, A., Golbaz, S., Bakhtiari, R., et al. (2020). Indoor and Outdoor Airborne Bacterial and Fungal Air Quality in Kindergartens: Seasonal Distribution, Genera, Levels, and Factors Influencing Their Concentration. Building Environ. 175, 106690. doi:10.1016/j.buildenv.2020.106690

Dacarro, C., Picco, A. M., Grisoli, P., and Rodolfi, M. (2003). Determination of aerial microbiological contamination in scholastic sports environments. J. Appl. Microbiol. 95, 904-912. doi:10.1046/j.1365-2672.2003.02044.x

Degobbi, C., Saldiva, P. H. N., and Rogers, C. (2011). Endotoxin as Modifier of Particulate Matter Toxicity: A Review of the Literature. Aerobiologia 27, 97-105. doi:10.1007/s10453-010-9179-6

Douwes, J., Thorne, P., Pearce, N., and Heederik, D. (2003). Bioaerosol Health Effects and Exposure Assessment: Progress and Prospects. Ann. Occup. Hyg. 47, 187-200. doi:10.1093/annhyg/meg032

Dumała, S., and Dudzińska, M. (2013). Microbiological Indoor Air Quality in Polish Schools. Annu. Set Environ. Prot. 15, 231-244.

Fisk, W. J. (2013). Health Benefits of Particle Filtration. Indoor Air. 23, 357-368. doi:10.1111/ina.12036

Gawrońska, H., and Bakera, B. (2015). Phytoremediation of Particulate Matter from Indoor Air by Chlorophytum Comosum L. Plants. Air Qual. Atmos. Health. 8, 265-272. doi:10.1007/s11869-014-0285-4

Gayer, A., Mucha, D., Adamkiewicz, Ł., and Badyda, A. (2018). Children Exposure to PM2.5 in Kindergarten Classrooms Equipped with Air Purifiers - a Pilot Study. MATEC Web Conf. 247, 00016. doi:10.1051/matecconf/201824700016

Ghasempour, M., Rajabnia, R., Irannejad, A., Hamzeh, M., Ferdosi, E., and Bagheri, M. (2013). Frequency, Biofilm Formation and Acid Susceptibility of Streptococcus Mutans and Streptococcus Sobrinus in Saliva of Preschool Children with Different Levels of Caries Activity. Dent Res. J. 10, 440. doi:10.4103/1735-3327.118478

Gorji, M., Bagherzadeh, R., and Fashandi, H. (2017). Electrospun Nanofibers in Protective Clothing. Electrospun Nanofibers, 571-598. doi:10.1016/B978-0-08100907-9.00021-0

Gołofit-Szymczak, M., and Górny, R. L. (2018). Microbiological Air Quality in Office Buildings Equipped with Dventilation Systems. Indoor Air. 28, 792-805. doi:10.1111/ina.12495

Jiayu, C., Qiaoqiao, R., Feilong, C., Chen, L., Jiguo, W., Zhendong, W., et al. (2019). Microbiology Community Structure in Bioaerosols and the Respiratory Diseases. J. Environ. Sci. Public Health. 03, 347-357. doi:10.26502/jesph.96120068

Kelly, F. J., and Fussell, J. C. (2015). Air Pollution and Public Health: Emerging Hazards and Improved Understanding of Risk. Environ. Geochem. Health. 37, 631-649. doi:10.1007/s10653-015-9720-1

Kelly, F. J., and Fussell, J. C. (2019). Improving Indoor Air Quality, Health and Performance within Environments where People Live, Travel, Learn and Work. Atmos. Environ. 200, 90-109. doi:10.1016/j.atmosenv.2018.11.058

Kim, K. Y., and Kim, C. N. (2007). Airborne Microbiological Characteristics in Public Buildings of Korea. Building Environ. 42, 2188-2196. doi:10.1016/ j.buildenv.2006.04.013

Kim, W., Ko, S., Oh, M., Choi, I.-j., and Shin, J. (2019). Is an Incentive Policy for Energy Efficient Products Effective for Air Purifiers? the Case of South Korea. Energies 12, 1664. doi:10.3390/en12091664

Kotzias, D. (2005). Indoor Air and Human Exposure Assessment - Needs and Approaches. Exp. Toxicologic Pathol. 57, 5-7. doi:10.1016/j.etp.2005.05.002

Lacey, J., and Dutkiewicz, J. (1994). Bioaerosols and Occupational Lung Disease. J. Aerosol Sci. 25, 1371-1404. doi:10.1016/0021-8502(94)90215-1

Lee, S. C., and Chang, M. (1986). Indoor and outdoor air quality investigation at schools in Hong Kong. Department of State publication. Background Notes Series $41,1-4$

Liebers, V., Raulf-Heimsoth, M., and Brüning, T. (2008). Health Effects Due to Endotoxin Inhalation (Review). Arch. Toxicol. 82, 203-210. doi:10.1007/ s00204-008-0290-1
Mentese, S., Arisoy, M., Rad, A. Y., and Güllü, G. (2009). Bacteria and Fungi Levels in Various Indoor and Outdoor Environments in Ankara, Turkey. Clean. Soil Air Water. 37, 487-493. doi:10.1002/clen.200800220

Morishita, M., Thompson, K. C., and Brook, R. D. (2015). Understanding Air Pollution and Cardiovascular Diseases: Is it Preventable? Curr. Cardiovasc. Risk Rep. 9. doi:10.1007/s12170-015-0458-1

Nasir, Z. A., and Colbeck, I. (2010). Assessment of Bacterial and Fungal Aerosol in Different Residential Settings. Water Air Soil Pollut. 211, 367-377. doi:10.1007/ s11270-009-0306-3

Nevalainen, A., Willeke, K., Liebhaber, F., Pastuszka, J. S., Burge, H., and Henningson, E. (1993). "Bioaerosol Sampling," in Aerosol Measurement: Principles, Techniques And Applications. Editors K. Willeke and P. Baron (New York: Van Nostrand Reinhold), 471-492.

Oh, H.-J., Nam, I.-S., Yun, H., Kim, J., Yang, J., and Sohn, J.-R. (2014). Characterization of Indoor Air Quality and Efficiency of Air Purifier in Childcare Centers, Korea. Building Environ. 82, 203-214. doi:10.1016/j.buildenv.2014.08.019

Oliveira, M., Slezakova, K., Delerue-Matos, C., Pereira, M. C., and Morais, S. (2019). Children Environmental Exposure to Particulate Matter and Polycyclic Aromatic Hydrocarbons and Biomonitoring in School Environments: A Review on Indoor and Outdoor Exposure Levels, Major Sources and Health Impacts. Environ. Int. 124, 180-204. doi:10.1016/j.envint.2018.12.052

Owen, M. K., Ensor, D. S., and Sparks, L. E. (1992). Airborne Particle Sizes and Sources Found in Indoor Air. Atmos. Environ. Part. A, Gen. Top. 26, 2149-2162. doi:10.1016/0960-1686(92)90403-8

Pastuszka, J. S. (2001). Exposure of the General Population Living in Upper Silesia Industrial Zone to the Particulate, Fibrous and Biological (Bacteria and Fungi) Aerosols. [in Polish]. Wroclaw, Poland: Wroclaw Technical University.

Pastuszka, J. S., Kyaw Tha Paw, U., Lis, D. O., Wlazło, A., and Ulfig, K. (2000). Bacterial and Fungal Aerosol in Indoor Environment in Upper Silesia, Poland. Atmos. Environ. 34, 3833-3842. doi:10.1016/S1352-2310(99)00527-0

Thorn, J. r., and Kerekes, E. (2001). Health Effects Among Employees in Sewage Treatment Plants: A Literature Survey. Am. J. Ind. Med. 40, 170-179. doi:10.1002/ajim.1085

Tolabi, Z., Alimohammadi, M., Hassanvand, M. S., Nabizadeh, R., Soleimani, H., and Zarei, A. (2019). The Investigation of Type and Concentration of BioAerosols in the Air of Surgical Rooms: A Case Study in Shariati Hospital, Karaj. MethodsX 6, 641-650. doi:10.1016/j.mex.2019.03.016

Tringe, S. G., Zhang, T., and Liu, X. (2008). The airbone metagenome in anindoor urban environment. PLOS ONE 20, 1-9. doi:10.1371/journal.pone.0001862

Wheeler, A. J., Gibson, M. D., MacNeill, M., Ward, T. J., Wallace, L. A., Kuchta, J., et al. (2014). Impacts of Air Cleaners on Indoor Air Quality in Residences Impacted by wood Smoke. Environ. Sci. Technol. 48, 12157-12163. doi:10.1021/es503144h

Who (2018). Air Pollution and Child Health.

Wood, R. A., Burchett, M. D., Orwell, R. A., Tarran, J., and Torpy, F. (2002). Plant/ soil Capacities to Remove Harmful Substances from Polluted Indoor Air. Available at: www.plants-for-people.de Accessed: April, 2021..

Yang, C. (2012). Aerosol Filtration Application Using Fibrous media - an Industrial Perspective. Chin. J. Chem. Eng. 20, 1-9. doi:10.1016/S1004-9541(12)60356-5

Zelles, L. (1999). Fatty Acid Patterns of Phospholipids and Lipopolysaccharides in the Characterisation of Microbial Communities in Soil: A Review. Biol. Fertil. Soils 29, 111-129. doi:10.1007/s003740050533

Conflict of Interest: The authors declare that the research was conducted in the absence of any commercial or financial relationships that could be construed as a potential conflict of interest.

Publisher's Note: All claims expressed in this article are solely those of the authors and do not necessarily represent those of their affiliated organizations, or those of the publisher, the editors, and the reviewers. Any product that may be evaluated in this article, or claim that may be made by its manufacturer, is not guaranteed or endorsed by the publisher.

Copyright (c) 2021 Bragoszewska and Biedron. This is an open-access article distributed under the terms of the Creative Commons Attribution License (CC $B Y$ ). The use, distribution or reproduction in other forums is permitted, provided the original author(s) and the copyright owner(s) are credited and that the original publication in this journal is cited, in accordance with accepted academic practice. No use, distribution or reproduction is permitted which does not comply with these terms. 